\title{
Core Histone Macro-H2A.2
}

National Cancer Institute

\section{Source}

National Cancer Institute. Core Histone Macro-H2A.2. NCI Thesaurus. Code C154659.

Core histone macro-H2A.2 (372 aa, $40 \mathrm{kDa}$ ) is encoded by the human MACROH2A2 gene. This protein plays a role in nucleosome formation and transcriptional repression. 